\title{
Filter Paper Blood Spot Enzyme Linked Immunoassay for Adiponectin and Application in the Evaluation of Determinants of Child Insulin Sensitivity
}

\author{
Richard M. Martin ${ }^{1,2,3 *}$, Rita Patel ${ }^{1}$, Emily Oken ${ }^{4}$, Jennifer Thompson ${ }^{4}$, Alexander Zinovik ${ }^{5}$, \\ Michael S. Kramer ${ }^{6,7}$, Konstantin Vilchuck ${ }^{5}$, Natalia Bogdanovich ${ }^{5}$, Natalia Sergeichick ${ }^{5}$, Ying Foo ${ }^{1}$, \\ Nina Gusina ${ }^{5}$
}

1 School of Social and Community Medicine, University of Bristol, Bristol, United Kingdom, 2 MRC Centre for Causal Analyses in Translational Epidemiology, School of Social and Community Medicine, University of Bristol, Bristol, United Kingdom, 3 University of Bristol/University Hospitals Bristol NHS Foundation Trust, National Institute for Health Research Bristol, Nutrition Biomedical Research Unit, University of Bristol, Bristol, United Kingdom, 4 Department of Population Medicine, Harvard Medical School and Harvard Pilgrim Health Care Institute, Boston, Massachusetts, United States of America, 5 National Research and Applied Medicine, Mother and Child Centre, Minsk, Republic of Belarus, 6 Department of Epidemiology, Biostatistics and Occupational Health, McGill University, Montreal, Quebec, Canada, 7 Department of Pediatrics, McGill University, Montreal, Quebec, Canada

\begin{abstract}
Background: Adiponectin is an adipocyte-derived hormone that acts as a marker of insulin sensitivity. Bloodspot sampling by fingerstick onto filter paper may increase the feasibility of large-scale studies of the determinants of insulin sensitivity. We first describe the validation of an enzyme-linked immunoassay (ELISA) for quantifying adiponectin from dried blood spots and then demonstrate its application in a large trial (PROBIT).

Methods: We quantified adiponectin from 3-mm diameter discs ( $\approx 3 \mu \mathrm{L}$ of blood) punched from dried blood spots obtained from: i) whole blood standards (validation); and ii) PROBIT trial samples (application) in which paediatricians collected blood spots from 13,879 children aged 11.5 years from 31 sites across Belarus. We examined the distribution of bloodspot adiponectin by demographic and anthropometric factors, fasting insulin and glucose.

Results: In the validation study, mean intra-assay coefficients of variation $(n=162)$ were $15 \%, 13 \%$ and $10 \%$ for 'low' $(6.78 \mu \mathrm{g} / \mathrm{ml})$, 'medium' $(18.18 \mu \mathrm{g} / \mathrm{ml})$ and 'high' $(33.13 \mu \mathrm{g} / \mathrm{ml})$ internal quality control (IQC) samples, respectively; the respective inter-assay values $(n=40)$ were $23 \%, 21 \%$ and $14 \%$. The correlation coefficient between 50 paired whole bloodspot versus plasma samples, collected simultaneously, was 0.87 ( $95 \% \mathrm{Cl}: 0.78$ to 0.93 ). Recovery of known quantities of adiponectin (between 4.5 to $36 \mu \mathrm{g} / \mathrm{ml}$ ) was $100.3-133 \%$. Bloodspot adiponectin was stable for at least 30 months at $-80^{\circ} \mathrm{C}$. In PROBIT, we successfully quantified fasting adiponectin from dried blood spots in 13,329 of $13,879(96 \%)$ children. Mean adiponectin (standard deviation) concentrations were $17.34 \mu \mathrm{g} / \mathrm{ml}(7.54)$ in boys and $18.41 \mu \mathrm{g} / \mathrm{ml}(7.92)$ in girls and were inversely associated with body mass index, fat mass, triceps and subscapular skin-fold thickness, waist circumference, height and fasting glucose.
\end{abstract}

Conclusions: Bloodspot ELISA is suitable for measuring adiponectin in very small volumes of blood collected on filter paper and can be applied to large-scale studies.

Citation: Martin RM, Patel R, Oken E, Thompson J, Zinovik A, et al. (2013) Filter Paper Blood Spot Enzyme Linked Immunoassay for Adiponectin and Application in the Evaluation of Determinants of Child Insulin Sensitivity. PLoS ONE 8(8): e71315. doi:10.1371/journal.pone.0071315

Editor: Raffaella Buzzetti, Sapienza, University, Italy

Received April 3, 2013; Accepted June 27, 2013; Published August 1, 2013

Copyright: (c) 2013 Martin et al. This is an open-access article distributed under the terms of the Creative Commons Attribution License, which permits unrestricted use, distribution, and reproduction in any medium, provided the original author and source are credited.

Funding: This work was supported by European Union, grant no. FOOD-DT-2005-007036; Early Nutrition Programming: Long-term Efficacy and Safety Trials; Canadian Institutes of Health Research (MOP - 53155); and the USA National Institutes of Health (reference: R01 HD 050758). The funders had no role in study design, data collection and analysis, decision to publish, or preparation of the manuscript.

Competing Interests: The authors have declared that no competing interests exist.

* E-mail: richard.martin@bristol.ac.uk

\section{Introduction}

There is substantial interest in large-scale epidemiology studies of the genetic and environmental determinants of insulin resistance, [1-10] which may inform strategies for the prevention of insulin resistance and its sequelae. [11] Adiponectin is an adipocyte-derived hormone that circulates in high concentrations in humans, moderating glycemia, lipidemia, endothelial dysfunction and proinflammatory mechanisms.[12-15] Higher levels of circulating adiponectin are inversely associated with obesity, especially central obesity, as well as hyperlipidemia, insulin resistance, $\beta$-cell dysfunction, and intramyocellular lipid accumulation,[16-23] both in children and in adults with risk of cardiovascular events.[13,24-26] These relationships, the fact that adiponectin levels are not materially affected by time of day or eating, and the low long-term intra-individual variation, [27] indicate that adiponectin could act as an integrated quantitative 


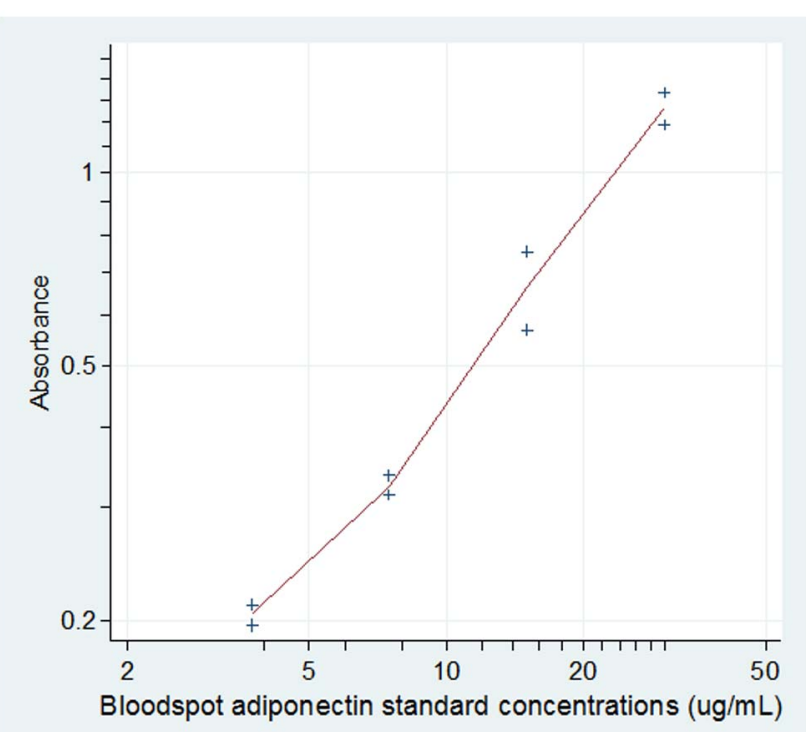

Figure 1. Typical calibration curve. Whole bloodspot adiponectin standards at $3.75,7.5,15.0,30.46 \mu \mathrm{g} / \mathrm{ml}$.

doi:10.1371/journal.pone.0071315.g001

measure of insulin sensitivity for use in epidemiology studies. $[20,28]$.

Important challenges in large-scale epidemiology include nonacceptance of venepuncture especially by children and/or their parents; the costs, safety and logistics of serum or plasma separation by centrifugation; and frozen storage and transport of aliquots. An alternative procedure to venepuncture involves capillary puncture of the finger pulp to collect whole blood spots that are then dried on filter paper. [29,30] The major advantages of dried blood spot sampling are minimal training, lower cost than venepuncture, acceptability to parents and children, [30] negligible processing requirements (cards must be air dried), low biohazard risk because samples cannot shatter or leak, and the ease of storage and transport of filter paper cards. [29,31].

As well as large-scale use of dried blood spots in paediatric screening programs for rare inherited disorders, there is widespread interest in developing and validating a wide range of bloodspot assays, [32] including adiponectin, [33] for population research. We first describe the validation of an enzyme-linked immunoassay (ELISA) for quantification of adiponectin from dried blood spots, which offers the important advantage that results can be read on universally available microtitre plate readers, without the need for regulatory approvals to use radioisotopes or more specialised and costly measuring equipment. Development and validation of an ELISA blood spot assay offers a simple, convenient and novel alternative method of measuring adiponectin in large-scale epidemiology studies in a wide range of settings. We then show the successful practical application of our dried blood spot assay in a large-scale, multicentre trial (the Promotion of Breastfeeding Intervention Trial, PROBIT [34]) by describing the distribution of fasting adiponectin levels by demographic and anthropometric factors, fasting insulin and glucose measured in over 13,000 children aged 11.5 years from 31 polyclinics distributed across the Republic of Belarus.

\section{Materials and Methods}

\section{Validation Study}

Materials. Blood samples were collected onto Food and Drug Administration approved Whatman 903 filter paper cards, [35] pre-printed with eight $10 \mathrm{~mm}$ diameter circles, standardized to absorb blood in a homogeneous manner so that uniform punches from any section of the sample yield the same quantity of blood. [36] We used an existing commercial kit, originally designed for use on serum or plasma (adiponectin human ELISA, EIA4177, DRG International Inc, New Jersey). The kit quantifies adiponectin using a solid phase, two-site enzyme-linked immunoassay, based on the direct sandwich technique in which two monoclonal antibodies are directed against separate antigenic determinants on the adiponectin molecule. Instruments used included an automatic filter paper card puncher (Wallac DBS (Dried Blood Spot) Puncher, product number: 1296-071, Perkin Elmer, USA), a microplate washing device (DELFIA WasherDiskremove, product number: 1296-0010 Perkin Elmer, USA), a plate shaker (DELFIA Plateshaker, product number:1296-003, Perkin Elmer, USA) and a microplate reader (VICTOR3 Multilabel Reader, product number: 1420-012, Perkin Elmer, USA).

Preparation of bloodspot adiponectin standards and internal quality control samples. We prepared whole blood adiponectin standards and internal quality control samples to minimize matrix differences and maximize comparability between the standards, quality control samples and the trial samples. For the standards, we collected whole blood by phlebotomy from a volunteer, centrifuged it, established the adiponectin concentration in plasma, double diluted it in phosphate buffered saline (PBS) and $1 \%$ human albumin to obtain levels of 3.75, 7.5, 15.0 and

Table 1. Intra- and inter-assay imprecision of dried whole bloodspot adiponectin assays.

\begin{tabular}{llll}
\hline & & & \multicolumn{2}{l}{$\begin{array}{l}\text { Mean standard deviation of } \\
\text { repeated measures }\end{array}$} & Coefficient of variation \\
\hline Intra-assay $(n=162)$ & & & 1.00 \\
Low & 6.78 & 2.41 & $13 \%$ \\
Medium & 18.18 & 3.47 & $10 \%$ \\
High & 33.13 & & $23 \%$ \\
Inter-assay $(n=40)$ & & 1.54 & $21 \%$ \\
Low & 6.78 & 3.73 & $14 \%$ \\
Medium & 18.18 & 4.53 & \\
High & 33.13 & & \\
\hline doi:10.1371/journal.pone.0071315.t001 & & & \\
\hline
\end{tabular}




\section{Low IQC}

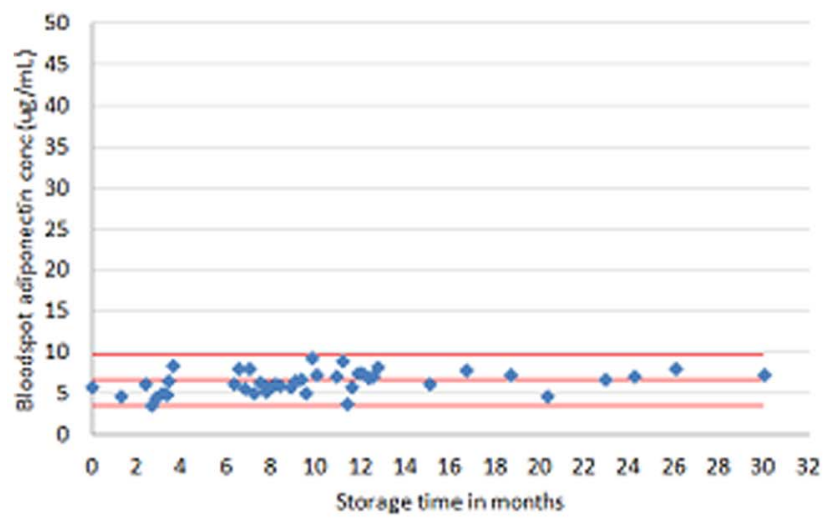

\section{MedIQC}

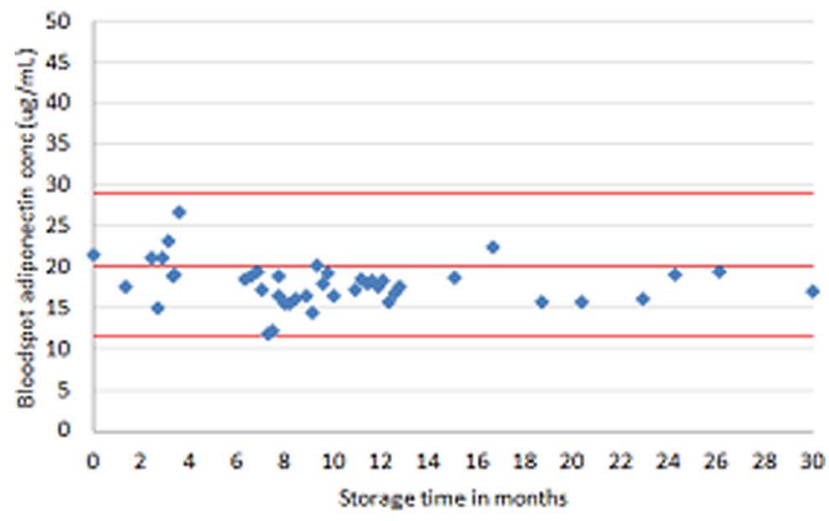

High IQC

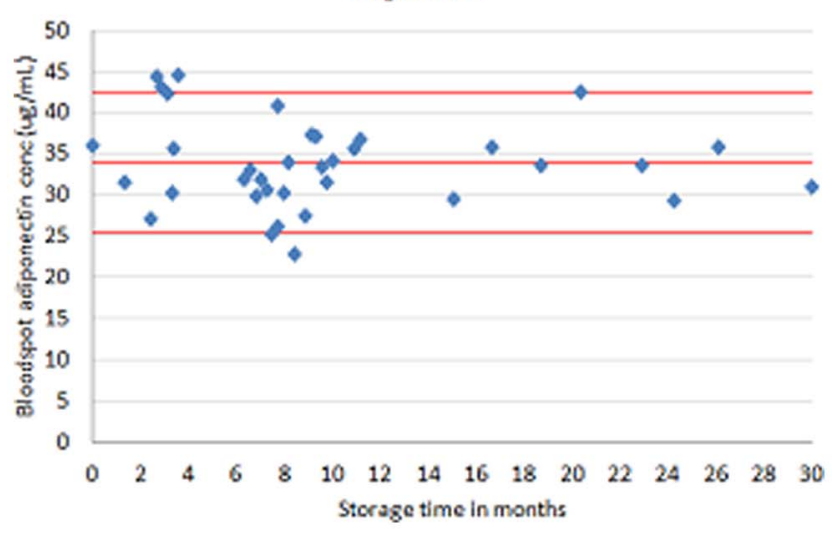

Figure 2. Stability of adiponectin concentrations (at A. low, B. medium and $C$. high values) measured from dried blood spots and stored at $-\mathbf{8 0}{ }^{\circ} \mathrm{C}$ for $\mathbf{3 0}$ months. Adiponectin concentrations of internal quality control (IQC) bloodspots (low, medium and high values) analysed at regular intervals over 30 months. For the 'low' IQC sample (Fig. 2A), the middle red line is the mean adiponectin concentration and the upper and lower red lines are the $95 \%$ reference range (calculated from the standard deviation of 24 replicates); the respective lines showing the mean and 95\% reference range for the 'medium' (Fig. 2B) and 'high' (Fig. 2C) IQC samples are also shown.

doi:10.1371/journal.pone.0071315.g002

$30.46 \mu \mathrm{g} / \mathrm{ml}$ (top standard). We then mixed each dilution with washed red blood cells (in proportions 60:40 for a 0.40 haematocrit) and applied drops to Whatman 903 filter paper.
Internal quality control samples were based on whole blood taken from 3 volunteers (with low, medium and high values) that was applied to Whatman 903 filter paper and the values assigned from the mean of 24 replicates of the assay.

Assay procedure. All frozen blood spot cards (see sample collection below) were brought to room temperature before being removed from the plastic bags for assaying. For each child, one 3mm disc $(\approx 3 \mu \mathrm{L}$ of blood) was punched from the blood spots (of the standards, quality control samples and the trial samples) using an automatic puncher into 96-well microtitre plates, precoated with a monoclonal anti-human adiponectin antibodies. Adiponectin was extracted from the disc by overnight incubation in a refrigerator with $300 \mu \mathrm{L}$ of assay buffer $(0.05 \mathrm{M}$ Phosphosaline containing $0.025 \mathrm{M}$ EDTA, 0.08\% Sodium Azide, 1\% BSA). Following incubation, the wells were washed 3 times with wash solution (Tris-buffered saline) to remove unbound enzyme labelled antibody and $20 \mu \mathrm{L}$ pre-titered biotinylated mouse anti-human adiponectin antibody was added to each well and incubated for 2 hours at room temperature on the plate shaker. Bound conjugate was detected by incubation with $100 \mu \mathrm{L}$ of enzyme solution (prefiltered streptavidin-horseradish peroxidise conjugate) and $100 \mu \mathrm{L}$ of substrate solution $\left(3,3^{\prime}, 5^{\prime} 5^{\prime}\right.$-tetramethylbenzidine in buffer, TMB), before adding $100 \mu \mathrm{L}$ of stop solution $(0.3 \mathrm{M} \mathrm{HCl})$ to terminate the peroxidase/TMB reaction and give a colorimetric endpoint that was read within 5 minutes at 450 and $590 \mathrm{~nm}$. The difference in absorbance units was plotted against the assigned concentration in $\mu \mathrm{g} / \mathrm{ml}$ of the whole blood filter paper standard values using a sigmoidal 4- or 5-parameter logistic equation on the $\log$ scale on both $\mathrm{x}$ and $\mathrm{y}$ axes. The concentration of the samples was read from the fitted standard curve. Samples with adiponectin levels above $40 \mu \mathrm{g} / \mathrm{mL}$ but $\leq 60 \mu \mathrm{g} / \mathrm{ml}(3.3 \%)$ were reanalyzed by a $1: 2$ dilution and those $>60 \mu \mathrm{g} / \mathrm{mL}(0.7 \%)$ reanalyzed by a $1: 4$ dilution. Adiponectin values between the top standard $(30 \mu \mathrm{g} / \mathrm{mL})$ and $40 \mu \mathrm{g} / \mathrm{ml}$ were assigned the observed value, after determining amongst a sample of 69 children that repeating the assay using double dilution for these levels made no material difference to the observed values. Samples with adiponectin levels less than the lowest standard $(3.75 \mu \mathrm{g} / \mathrm{ml}, 0.8 \%)$ were repeated.

Inter- and intra-assay imprecision. Inter- and intra-assay imprecision was assessed using internal quality control samples at three levels: 'low' (6.78 $\mu \mathrm{g} / \mathrm{ml})$, 'medium' (18.18 $\mu \mathrm{g} / \mathrm{ml})$ and 'high' $(33.13 \mu \mathrm{g} / \mathrm{ml})$. Intra-assay imprecision was established from duplicate analysis $(\mathrm{n}=162)$ and inter-assay imprecision was determined from 40 separate runs over a period of 29 months. Inter-assay samples were run in duplicate and both intra- and inter-assay imprecision include between-spot extraction variations.

Stability. To assess stability at $-80^{\circ} \mathrm{C}$ over the long-term, the whole blood samples used to provide the internal quality controls were spotted onto Whatman 903 cards, cut into strips containing one blood spot per strip, and frozen at $-80^{\circ} \mathrm{C}$. Initially with every run (for 34 weeks) and then at regular intervals for a total period of 30 months, a different strip was thawed (to ensure levels were based on only one thaw) and the blood spot adiponectin value measured in duplicate.

Recovery. We assessed recovery by diluting plasma with an adiponectin concentration of $36 \mathrm{ug} / \mathrm{ml}$ with buffered saline to concentrations of $18,9,4.5$ and $0 \mathrm{ug} / \mathrm{ml}$, mixing the plasma with erythrocytes in the ratio 60:40, spotting onto Whatman 903 cards and determining the values retrieved after applying the blood spot assay protocol in triplicate.

Comparison between plasma and dried blood spots. We compared adiponectin concentrations in plasma (measured using the adiponectin human ELISA, EIA4177, DRG International Inc, New Jersey) with concentrations measured from dried blood spots, 


\section{Adiponectin}

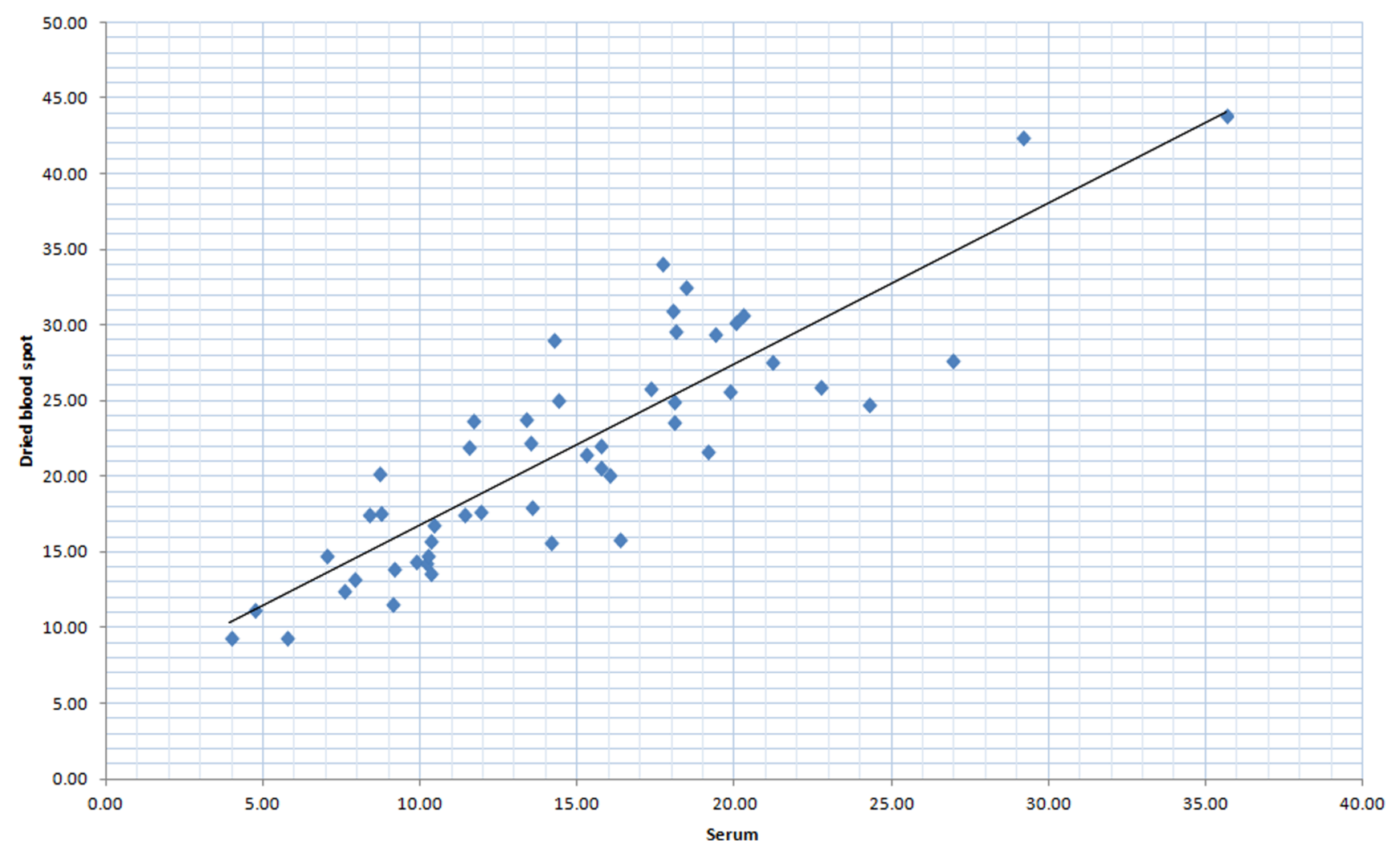

Figure 3. Comparison of adiponectin concentrations measured from 50 paired plasma and whole bloodspot samples. doi:10.1371/journal.pone.0071315.g003

collected simultaneously from 50 children in Minsk. Whole blood samples were allowed to stand at room temperature for $2-4$ hours then centrifuged at $3000 \mathrm{rpm}$ for 5 minutes before separating the plasma. Blood spots and plasma were stored at $-80^{\circ} \mathrm{C}$ and brought to room temperature before assaying, performed in duplicate for both plasma and dried blood spot samples.

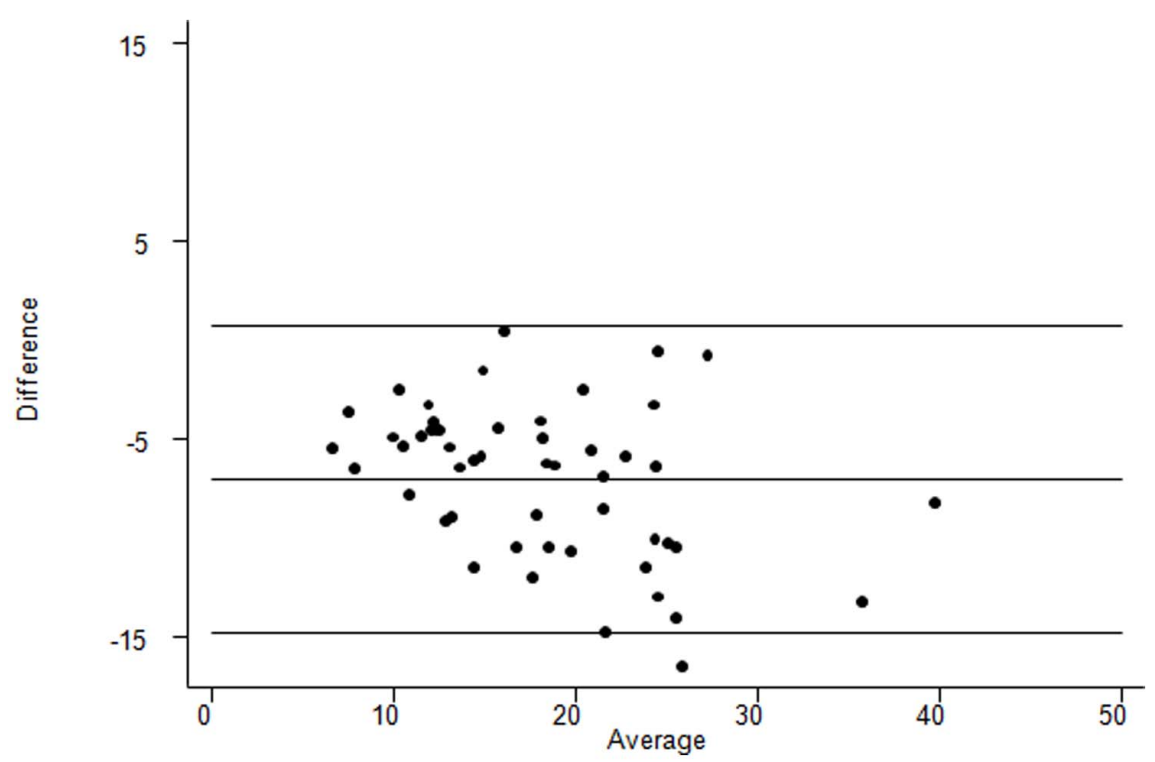

Figure 4. Bland-Altman plot for plasma adiponectin minus bloodspot adiponectin values in $\mathbf{5 0}$ paired samples. Limits of agreement (reference range for the difference): -14.8 to $0.68 \mu \mathrm{g} / \mathrm{ml}$. Mean difference in adiponectin between plasma minus blood spot samples: $-7.1 \mu \mathrm{g} / \mathrm{ml}$ ( $95 \% \mathrm{Cl}:-8.2$ to -6.0 ). Range of average values: 6.7 to $39.8 \mu \mathrm{g} / \mathrm{ml}$.

doi:10.1371/journal.pone.0071315.g004 
Table 2. Recovery of adiponectin from five different dried blood spot concentrations.

\begin{tabular}{lll}
\hline & & \\
\hline Adiponectin in whole blood $(\mu \mathbf{g} / \mathbf{m l})$ & Adiponectin in dried blood $(\mu \mathbf{g} / \mathbf{m l})$ & Recovery, \% \\
\hline 0 & 0.34 & - \\
4.5 & 5.84 & $130 \%$ \\
9.0 & 9.025 & $100.3 \%$ \\
18 & 20.14 & $111.9 \%$ \\
36 & 48.04 & $133 \%$ \\
\hline
\end{tabular}

doi:10.1371/journal.pone.0071315.t002

\section{Application of Methods}

Distribution of adiponectin by demographic and clinical characteristics. We followed up 13,879 children aged 11.5 years (interquartile range 11.3-11.8 years) who were participants in a multicentre trial of a breastfeeding promotion intervention involving 31 polyclinics (39 paediatricians) located throughout the Republic of Belarus. [34] Children who were eligible for the trial (healthy, term newborns whose mother initiated breastfeeding) were originally recruited at birth between 1996 and 1997, [34] and have been followed up intermittently since then, including the 11.5 year follow-up reported here between 2008-2010. At 11.5 years, dried blood spots were collected from the children as described below. The children also had fasted insulin measured from dried blood spots as described previously, [37] whole blood fasting glucose measured by glucometer (Roche ACCU-CHEK Advantage meter system, F. Hoffmann-La Roche AG, Basel, Switzerland) and the following physical measurements (amongst others not reported here) were made by study paediatricians: Tanner pubertal stage, height, weight, body mass index (BMI, weight $(\mathrm{kg}) /$ height $\left.(\mathrm{m})^{2}\right)$, skinfold thicknesses, waist circumference and leg-to-leg bioimpedence (Tanita TBF 300GS, Tanita Europe BV, Netherlands) for calculation of fat-mass. Birthweight had been collected when the children were recruited into the trial at birth in 1996/1997. [34].

Sample collection. The protocol for sample collection, quality assurance processes, and the detailed training received by the paediatricians in obtaining blood spots, has been reported in detail elsewhere. [37] In brief, children in the PROBIT trial follow-up were asked to fast for at least 8 hours. Up to 8 drops of fingertip capillary blood were obtained by trained paediatricians using a sterile, single-use disposable lancet device (Roche ACCUCHEK Safe-T-Pro Plus lancet, Roche Diagnostics Corp., Indianapolis, USA) and applied to the pre-printed circles to form one discrete spot per drop, following specific guidelines. [35,38] The blood spots were air-dried and then placed in low gaspermeable zip-closure plastic bags with desiccant packages. [36] These were stored initially in $-20^{\circ} \mathrm{C}$ freezers at the 31 polyclinics, prior to transfer in cool boxes packed with freezer packs to $-80^{\circ} \mathrm{C}$ freezers at the central laboratory in Minsk. The samples were stored at $-20^{\circ} \mathrm{C}$ for a median of 1.6 months (IQR $1.0-5.0$ months) and at $-80^{\circ} \mathrm{C}$ for a median of 16.9 (IQR 11.9-20.2) months. At the central laboratory in Minsk, 432 samples were assayed in 5 plates per week, using 4 separate assay lots. Assays were run in singleton and repeated if they failed quality control parameters. It took 34 weeks to complete the study.

Audit. Once data collection was complete, we conducted audit visits to assess the inter-observer reproducibility, an important step given that the pediatricians were not blinded to randomization status. For each of the 39 pediatricians, 1-5 children were randomly selected for the audit, for a total of 127 audited children with baseline and repeat adiponectin values. So that all children seen in follow-up were eligible for selection, the

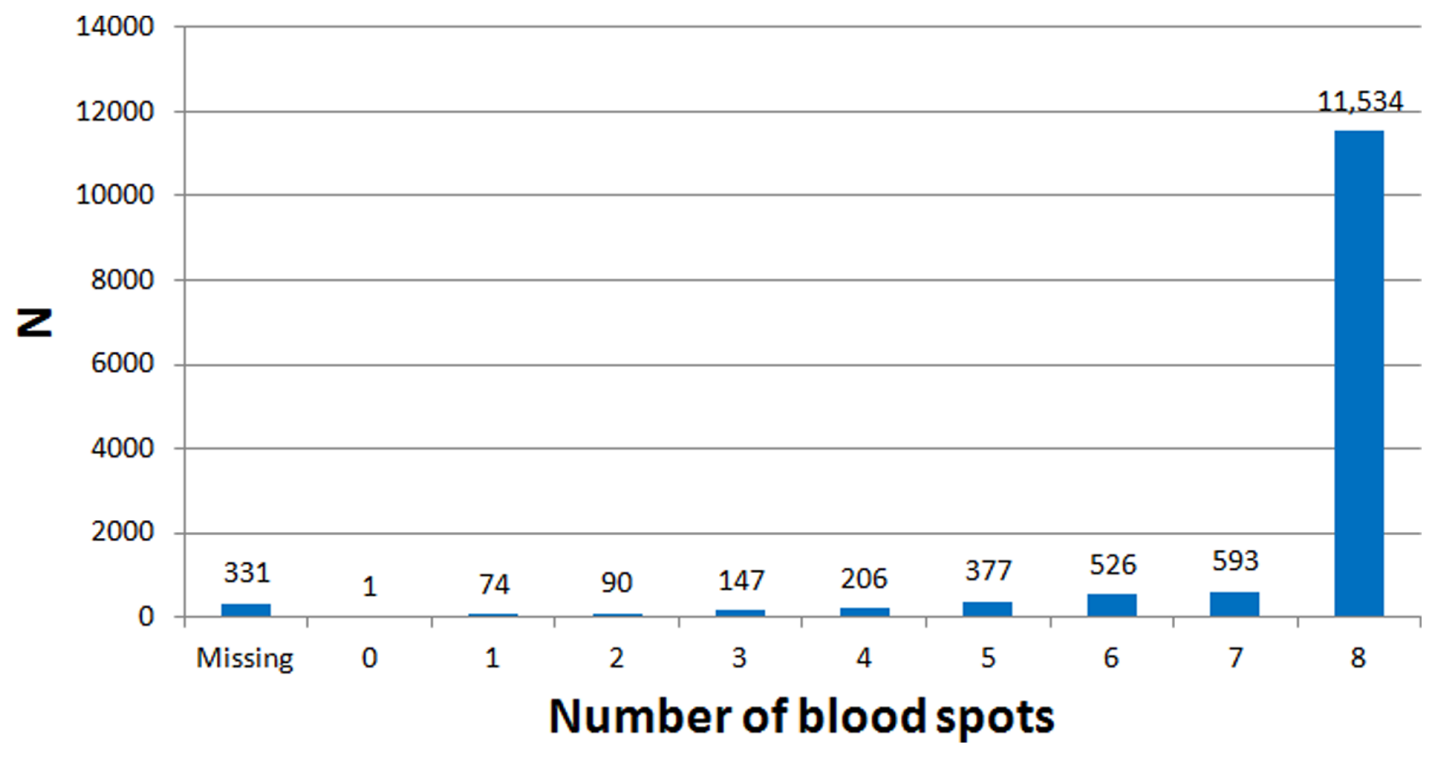

Figure 5. Number of blood spots per child collected in the PROBIT study when the children were aged 11.5 years. doi:10.1371/journal.pone.0071315.g005 
Table 3. Adiponectin levels in boys and girls by demographic and clinical characteristics, $\mathrm{N}=13,329$.

\begin{tabular}{|c|c|c|c|c|c|}
\hline & \multicolumn{4}{|c|}{$\begin{array}{l}\text { Adiponectin levels }(\mu \mathrm{g} / \mathrm{ml}) \text { and age-adjusted difference in adiponectin } \\
(95 \% \mathrm{Cl}) \text { per unit of demographic/clinical variable }\end{array}$} & \multirow[b]{2}{*}{$\begin{array}{l}p \text { for sex } \\
\text { interaction }\end{array}$} \\
\hline & $\mathbf{N}$ & Girls & $\mathbf{N}$ & Boys & \\
\hline \multicolumn{6}{|l|}{ Age group (yrs) } \\
\hline $10-<11$ & 407 & $17.6(7.3)$ & 422 & $17.0(7.5)$ & \\
\hline $11-<12$ & 4949 & $18.6(7.9)$ & 5191 & $17.5(7.6)$ & \\
\hline $12-<13$ & 1012 & $18.2(7.9)$ & 1108 & $17.0(7.3)$ & \\
\hline $13-<14$ & 110 & $14.0(7.3)$ & 130 & $13.8(5.1)$ & \\
\hline Change in adiponectin per year ${ }^{a}$ & & $-0.50(-1.84,0.83)$ & & $-0.61(-1.35,0.13)$ & 0.77 \\
\hline \multicolumn{6}{|l|}{ Location } \\
\hline Rural & 2738 & $18.6(7.9)$ & 2860 & $17.5(7.8)$ & \\
\hline Urban & 3740 & $18.3(7.9)$ & 3991 & $17.2(7.3)$ & \\
\hline Difference in adiponectin ${ }^{a}$ & & $0.34(-1.00,1.68)$ & & $0.33(-0.78,1.45)$ & 0.96 \\
\hline East & 3114 & $18.3(7.9)$ & 3179 & $17.3(7.5)$ & \\
\hline West & 3364 & $18.5(7.9)$ & 3672 & $17.3(7.5)$ & \\
\hline Difference in adiponectin ${ }^{a}$ & & $-0.17(-1.48,1.14)$ & & $-0.02(-1.16,1.11)$ & 0.60 \\
\hline \multicolumn{6}{|c|}{ Tanner stage by breast (girls)/genitalia (boys) } \\
\hline 1 & 745 & $18.4(7.5)$ & 897 & $16.9(7.3)$ & \\
\hline II & 3323 & $18.7(8.1)$ & 3699 & $17.6(7.7)$ & \\
\hline IIII & 2080 & $18.1(7.8)$ & 1995 & $17.0(7.3)$ & \\
\hline IV/V & 325 & $17.4(6.9)$ & 252 & $17.9(7.9)$ & \\
\hline Change in adiponectin per category ${ }^{a}$ & & $-0.37(-0.87,0.14)$ & & $-0.001(-0.61,0.61)$ & 0.20 \\
\hline \multicolumn{6}{|c|}{ Tanner stage by pubic hair assessment } \\
\hline I & 1819 & $18.6(8.0)$ & 3440 & $17.6(7.7)$ & \\
\hline II & 3035 & $18.5(8.0)$ & 2808 & $17.3(7.4)$ & \\
\hline IIII & 1434 & $17.9(7.6)$ & 546 & $16.4(6.8)$ & \\
\hline IV/V & 185 & $18.7(7.0)$ & 49 & $15.0(6.4)$ & \\
\hline Change in adiponectin per category ${ }^{a}$ & & $-0.24(-0.71,0.23)$ & & $-0.50(-0.90,-0.10)$ & 0.15 \\
\hline \multicolumn{6}{|l|}{ Body mass index $\left(\mathbf{k g} / \mathbf{m}^{2}\right)^{b}$} \\
\hline Normal weight & 5627 & $18.70(7.93)$ & 5668 & $17.61(7.57)$ & \\
\hline Overweight & 607 & $17.21(7.68)$ & 738 & $16.49(7.38)$ & \\
\hline Obese & 240 & $14.97(6.85)$ & 439 & $15.53(7.02)$ & \\
\hline Change in adiponectin per category ${ }^{a}$ & & $-1.73(-2.06,-1.39)$ & & $-1.06(-1.42,-0.70)$ & 0.003 \\
\hline \multicolumn{6}{|l|}{ Fat mass (kg) } \\
\hline$<90^{\text {th }}$ centile & 5913 & $18.6(7.9)$ & 6128 & $17.5(7.5)$ & \\
\hline$\geq 90^{\text {th }}$ centile $^{d}$ & 652 & $16.4(7.5)$ & 688 & $15.9(7.3)$ & \\
\hline Difference in adiponectin ${ }^{a}$ & & $-2.19(-2.65,-1.72)$ & & $-1.60(-2.29,-0.90)$ & 0.10 \\
\hline \multicolumn{6}{|l|}{ Triceps thickness (mm) } \\
\hline$<90^{\text {th }}$ centile & 5900 & $18.6(8.0)$ & 6149 & $17.5(7.5)$ & \\
\hline$\geq 90^{\text {th }}$ centile $^{d}$ & 724 & $16.5(7.0)$ & 699 & $16.4(7.3)$ & \\
\hline Difference in adiponectin ${ }^{a}$ & & $-2.15(-2.93,-1.38)$ & & $-1.03(-1.71,-0.35)$ & 0.004 \\
\hline \multicolumn{6}{|l|}{ Subscapular thickness (mm) } \\
\hline$<90^{\text {th }}$ centile & 6214 & $18.5(7.9)$ & 6567 & $17.4(7.5)$ & \\
\hline$\geq 90^{\text {th }}$ centile $^{d}$ & 258 & $15.1(6.4)$ & 282 & $15.5(7.0)$ & \\
\hline Difference in adiponectin ${ }^{a}$ & & $-3.40(-4.14,-2.67)$ & & $-1.91(-2.64,-1.19)$ & 0.001 \\
\hline \multicolumn{6}{|l|}{ Waist circumference $(\mathrm{cm})$} \\
\hline$<90^{\text {th }}$ centile & 6106 & $18.6(7.9)$ & 6704 & $17.5(7.5)$ & \\
\hline$\geq 90^{\text {th }}$ centile $^{c}$ & 369 & $15.6(7.0)$ & 305 & $15.3(7.2)$ & \\
\hline Difference in adiponectin ${ }^{a}$ & & $-2.23(-2.67,-1.79)$ & & $-1.53(-2.21,-0.85)$ & 0.08 \\
\hline
\end{tabular}


Table 3. Cont.

\begin{tabular}{|c|c|c|c|c|c|}
\hline & \multicolumn{4}{|c|}{$\begin{array}{l}\text { Adiponectin levels }(\mu \mathrm{g} / \mathrm{ml}) \text { and age-adjusted difference in adiponectin } \\
(95 \% \mathrm{Cl}) \text { per unit of demographic/clinical variable }\end{array}$} & \multirow[b]{2}{*}{$\begin{array}{l}p \text { for sex } \\
\text { interaction }\end{array}$} \\
\hline & $\mathbf{N}$ & Girls & $\mathbf{N}$ & Boys & \\
\hline Q1 & 2036 & $18.9(8.1)$ & 2013 & $17.7(7.5)$ & \\
\hline Q2 & 1627 & $18.3(8.0)$ & 1822 & $17.7(7.6)$ & \\
\hline Q3 & 1460 & $18.2(7.9)$ & 2022 & $17.1(7.5)$ & \\
\hline Q4 & 1355 & $17.9(7.5)$ & 992 & $16.5(7.4)$ & \\
\hline Change in adiponectin per $10 \mathrm{~cm}^{a}$ & & $-0.47(-0.86,-0.07)$ & & $-0.49(-0.85,-0.14)$ & 0.79 \\
\hline \multicolumn{6}{|l|}{ Birthweight $(\mathbf{g})^{f}$} \\
\hline Q1 & 1819 & $18.0(7.9)$ & 1748 & $17.0(7.4)$ & \\
\hline Q2 & 1466 & $18.4(7.8)$ & 1851 & $17.4(7.5)$ & \\
\hline Q3 & 1579 & $18.6(8.0)$ & 1776 & $17.5(7.6)$ & \\
\hline Q4 & 1614 & $18.7(7.9)$ & 1476 & $17.4(7.6)$ & \\
\hline Change in adiponectin per $100 g^{a}$ & & $0.07(0.03,0.11)$ & & $0.03(-0.02,0.08)$ & 0.16 \\
\hline \multicolumn{6}{|l|}{ Glucose(mmol/l) } \\
\hline Q1 & 1569 & $19.5(8.0)$ & 1979 & $17.9(7.5)$ & \\
\hline Q2 & 1601 & $19.1(8.1)$ & 1337 & $17.9(7.9)$ & \\
\hline Q3 & 1521 & $17.9(7.8)$ & 1628 & $17.3(7.5)$ & \\
\hline Q4 & 1778 & $17.3(7.6)$ & 1902 & $16.5(7.3)$ & \\
\hline $\begin{array}{l}\text { Change in adiponectin per SD increase } \\
\text { in glucose } e^{a}\end{array}$ & & $-0.55(-0.89,-0.22)$ & & $-0.55(-0.89,-0.21)$ & 0.96 \\
\hline \multicolumn{6}{|l|}{ Insulin (mU/L) } \\
\hline Q1 & 1570 & $17.6(7.6)$ & 1626 & $16.8(7.2)$ & \\
\hline Q2 & 1578 & $18.6(7.8)$ & 1630 & $17.4(7.4)$ & \\
\hline Q3 & 1578 & $19.0(8.3)$ & 1628 & $17.7(7.6)$ & \\
\hline Q4 & 1582 & $18.4(7.8)$ & 1638 & $17.7(7.9)$ & \\
\hline $\begin{array}{l}\text { Change in adiponectin per SD increase } \\
\text { in insulin }{ }^{a}\end{array}$ & & $0.20(-0.03,0.44)$ & & $0.004(-0.19,0.20)$ & 0.07 \\
\hline $\begin{array}{l}\mathrm{SD}=\text { standard deviation; } \mathrm{Cl}=\text { confiden } \\
\text { a Linear regression coefficient and } 95 \% \\
\text { b Normal weight, overweight and obe } \\
\text { cCentiles derived from NHANES Euror } \\
{ }^{\mathrm{d} C} \text { Centile derived from sample. } \\
\text { e Quartiles derived from NHSR age-an } \\
{ }^{f} \text { Quartiles derived from sample. } \\
\text { doi:10.1371/journal.pone.0071315.t00 }\end{array}$ & $\begin{array}{l}\text { nce inte } \\
\% \mathrm{Cl} \text { (as } \\
\text { ese as d } \\
\text { pean as } \\
\text { id sex-s } \\
3\end{array}$ & $\begin{array}{l}\text { djusted, accounting for } \\
\text { ed by the International } \\
\text { nd sex-specific thresholc } \\
\text { fic thresholds [46]. }\end{array}$ & $\begin{array}{l}\text { polyc } \\
\text { Force } \\
\text { [45]. }\end{array}$ & ut-offs. [44]. & \\
\hline
\end{tabular}

audit was carried out after completion of primary data collection, an average of 1.3 years (range 0.2 to 2.4 years) after the initial clinic visit. The audit was carried out by one of five Minsk-based pediatricians not involved in primary data collection and blinded to the measures obtained at the initial visit but not to experimental or control status. Because of the time elapsed between the audit and initial visits, results were compared using Spearman correlation coefficients.

Ethics. The study received ethical approval from McGill University Health Centre Research Ethics Board; the Human Subjects Committee at Harvard Pilgrim Health Care; and the Avon Longitudinal Study of Parents and Children Law and Ethics Committee. The conduct of the study was also approved by the Ministry of Health of the Republic of Belarus. A parent or legal guardian provided written informed consent and all children provided written assent. The trial registration number is ISRCTN37687716 for Current Controlled Trials and NCT01561612 for Clinicaltrials.gov.
Statistical analysis. Calibration curves were constructed with Multicalc software (Wallac, Turku, Finland), using the log scale for both $\mathrm{x}$ and $\mathrm{y}$ axes. To assess the relationship between adiponectin values from plasma versus whole blood spot samples collected simultaneously, we computed the correlation coefficient (95\% confidence interval) and constructed a Bland-Altman plot of the difference between the plasma and bloodspot adiponectin values (y-axis) against the mean of these two values ( $\mathrm{x}$-axis). Using data from the PROBIT study, we performed linear regression accounting for clustering by polyclinic to investigate relationships of adiponectin levels with child age, location of polyclinic (urban/ rural; East/West Belarus), puberty as measured by Tanner stage, measures of general (BMI, fat mass, peripheral (triceps skinfold thickness) and central (subscapular skinfold thickness, waist circumference) adiposity, height, birthweight and fasting glucose, and insulin. We calculated sex-specific associations and performed a likelihood ratio test for interactions between sex and the demographic, glucose, insulin and anthropometric factors on adiponectin. We also performed a likelihood ratio interaction test 
Table 4. Comparison of adiponectin levels measured in PROBIT with other studies in children of a similar age.

\begin{tabular}{|c|c|c|c|c|}
\hline \multirow[b]{2}{*}{$\begin{array}{l}\text { Study (ordered by subjects' } \\
\text { age) }\end{array}$} & \multirow[b]{2}{*}{$\begin{array}{l}\text { Mean age, years (SD, unless } \\
\text { otherwise stated) }\end{array}$} & \multirow[b]{2}{*}{ Number } & \multicolumn{2}{|c|}{ Adiponectin levels $(\mu \mathrm{g} / \mathrm{ml})$} \\
\hline & & & Mean/median & SD (unless otherwise stated) \\
\hline \multicolumn{5}{|l|}{ Girls } \\
\hline Ong [42] & $8.2(8.1-8.2)^{\mathrm{a}}$ & 390 & 14.0 & $11.4-17.6^{b}$ \\
\hline PROBIT & $11.5(11.3-11.8)^{\mathrm{a}}$ & 6478 & 18.4 & 7.9 \\
\hline Okada [39] & $11.6(1.5)$ & 139 & 15.4 & 7.1 \\
\hline Punthakee [41] & 13 & 235 & 10.9 & $10.4-11.4^{c}$ \\
\hline Singhal [40] & $14.9(0.9)$ & 160 & 7.6 & $5.6-10.6^{\mathrm{b}}$ \\
\hline \multicolumn{5}{|l|}{ Boys } \\
\hline Ong [42] & $8.2(8.1-8.2)^{\mathrm{a}}$ & 449 & 13.0 & $11.1-16.0^{\mathrm{b}}$ \\
\hline PROBIT & $11.5(11.3-11.8)^{\mathrm{a}}$ & 6851 & 17.35 & 7.5 \\
\hline Okada [39] & $11.6(1.5)$ & 144 & 13.7 & 6.1 \\
\hline Punthakee [41] & 13 & 269 & 9.1 & $8.6-9.5^{c}$ \\
\hline Singhal [40] & $15.0(0.9)$ & 134 & 6.4 & $4.7-9.5^{\mathrm{b}}$ \\
\hline
\end{tabular}

of whether the association of adiponectin with insulin levels varied by whether the children were overweight/obese versus normal weight. Analyses were undertaken using Stata version 11 (StataCorp LP, Texas) and SAS version 9.3 (SAS Institute, Inc., Cary, North Carolina).

\section{Results}

A typical calibration curve is shown in Figure 1. The precision of the dried blood spot extraction and consecutive determination by ELISA is summarised in Table 1. Mean intra-assay $(\mathrm{n}=162)$ coefficients of variation were $15 \%, 13 \%$ and $10 \%$ for 'low' $(6.78 \mu \mathrm{g} / \mathrm{ml})$, 'medium' $(18.18 \mu \mathrm{g} / \mathrm{ml})$ and 'high' $(33.13 \mu \mathrm{g} / \mathrm{ml})$ IQG samples, respectively; the respective inter-assay values $(\mathrm{n}=40)$ were $23 \%, 21 \%$ and $14 \%$.

The results of the 30 month long-term stability study at $-80^{\circ} \mathrm{C}$ are shown in Figure 2. Over the 30 months, most values were within the $95 \%$ reference range established from 24 replicates of the time 0 value, although there were month-by-month fluctuations in line with the inter-assay imprecision of measurements. In linear regression analyses, adjusted for lot number, there was no evidence of any association between storage time at $-80^{\circ} \mathrm{C}$ and levels of adiponectin for the low (change in adiponectin levels per month $=0.04 \mu \mathrm{g} / \mathrm{ml} ; 95 \%$ CI: -0.04 to $0.12 ; \mathrm{p}=0.33$ ), medium $(0.05 \mu \mathrm{g} / \mathrm{ml} ; 95 \% \mathrm{CI}:-0.12$ to $0.22 ; \mathrm{p}=0.53)$, or high $(0.07 \mu \mathrm{g} /$ $\mathrm{ml}$; $95 \%$ CI: -0.30 to $0.44 ; \mathrm{p}=0.70)$ internal quality control samples.

\section{Comparison of Samples and Recovery}

Comparison of 50 paired fasted whole bloodspots and plasma samples samples collected simultaneously gave a correlation coefficient of 0.87 (95\% CI: 0.78 to 0.93) (Figure 3), the range of plasma values being 3.9 to $35.7 \mu \mathrm{g} / \mathrm{ml}$. The Bland Altman plot shows that the $95 \%$ limits of agreement were between -14.8 to $0.68 \mu \mathrm{g} / \mathrm{ml}$ with a mean difference (plasma minus blood spot) across the range of values of $-7.1 \mu \mathrm{g} / \mathrm{ml}$ (CI -8.2 to -6.0 ), indicating that blood spot measurement of adiponectin was higher on average than plasma measurement (Figure 4). Inference was similar when the Bland-Altman plot was based on the ratio of bloodspot to plasma adiponectin values (Figure S1) Recovery of known quantities of adiponectin (between 4.5 to $36 \mu \mathrm{g} / \mathrm{ml}$ ) was $100.3-133 \%$ (Table 2).

\section{Associations of Adiponectin with Demographic and Clinical Variables}

Out of a total of 13,879 children who were approached, 13,547 $(97.6 \%)$ provided at least one acceptable dried blood spot sample (Figure 5). Amongst the 13,547 children, the paediatricians collected a median of 8 blood spots, with $85.1 \%(11,534)$ of children assessed by the central laboratory in Minsk as having had 8 acceptable quality blood spots collected. We assayed a total of 13,329 children who fasted for 8 or more hours for adiponectin.

Table 3 shows adiponectin levels in boys and girls by demographic and clinical variables. Mean adiponectin (standard deviation) concentrations were $17.34 \mu \mathrm{g} / \mathrm{ml}$ (7.54) in boys and $18.41 \mu \mathrm{g} / \mathrm{ml}(7.92)$ in girls ( $p$ for gender difference $<0.001$ ). Concentrations of adiponectin were inversely associated with Tanner stage by public hair assessment (boys). Adiponectin concentrations were also inversely associated with body mass index, fat mass, mean triceps and subscapular thicknesses, waist circumference, height and fasting glucose concentrations. There was evidence of an interaction between sex and body mass index, mean triceps thickness and mean subscapular thickness $(p$ for interaction $<0.01$ ), although the direction of the effects in both boys and girls was inverse. There was little evidence that the null association of adiponectin with insulin levels varied by whether the children were overweight/obese versus normal weight ( $p$ for interaction $=0.15$ ). The audit results between initial clinic results and blinded repeat (audit) measures of adiponectin showed a Spearman correlation coefficient of 0.33 . 


\section{Discussion}

We have shown that adiponectin in dried blood spots is stable and can be reliably quantified on a very large-scale with modest infrastructure, making the method useful for population-based studies of adiposity, insulin resistance, diabetes and cardiovascular risk in a variety of settings. Our data support a previous paper reporting on the quantification of adiponectin in dried blood spots from neonates in a small retrospective case-control study $(\mathrm{n}=124)$. [33] The advantages of fingerstick blood collection onto filter paper include ease of collection, processing, storage and transport, thus providing a valuable research tool for large epidemiology studies, particularly those that are geographically dispersed.

The dried blood spot methods showed acceptable analytical performance characteristics and good agreement with the conventional plasma adiponectin assay across the distribution of adiponectin values. There are several sources of variation unique to bloodspot sampling and the assay that could explain differences between bloodspot versus plasma. For example, proper placement of the whole blood sample on the filter paper is critical and errors can be introduced if blood is blotted or smeared rather than drawn onto the filter paper by capillary action. [32] We minimised this source of error by rigorous training and regular feedback. [37] Pre-printed circles on the filter paper were used to help guide the paediatricians to position the bloodspot. To maximise stability, samples were placed in zip-closure bags packed with dessicant and frozen at $-20^{\circ} \mathrm{C}$ promptly after drying to reduce the chances of degradation. These sources of variation are not seen with venepuncture sampling and the coefficients of variation reported in Table 1 were larger than those reported in the adiponectin kit insert (adiponectin human ELISA, EIA4177, DRG International Inc, New Jersey): $7.4 \%, 0.9 \%$ and $1.8 \%$ for 'low' $(17.73 \mu \mathrm{g} / \mathrm{ml})$, 'medium' (29.13 $\mu \mathrm{g} / \mathrm{ml})$ and 'high' $(39.10 \mu \mathrm{g} / \mathrm{ml})$ serum samples, respectively; the respective inter-assay values were $8.4 \%, 2.4 \%$ and $6.2 \%$. The haematocrit level was set to 0.4 in the standards but not adjusted for in each sample; any sample differences would introduce errors. The variation seen in Figure $\mathbf{2}$ is broadly in line with the imprecision suggested in Table 1. Despite unique sources of error, we achieved a good correlation between dried blood spot versus plasma methods of measurement.

In our fieldwork study, we showed that taking capillary blood samples from children is feasible on a large scale, since only $2.4 \%$ ( $\mathrm{n}=332$ ) of 13,879 children approached did not provide a useable sample and the paediatricians were able to take a median of 8 acceptable blood spots amongst those who were sampled.

\section{References}

1. Kuh D, Ben-Shlomo Y (1997) A life course approach to chronic disease epidemiology. Oxford: OUP.

2. Barker DJP (1998) Mothers, babies and health in later life. London: Churchill Livingstone.

3. Singhal A, Lucas A (2004) Early origins of cardiovascular disease: is there a unifying hypothesis? Lancet 363: 1642-1645.

4. Lawlor DA, Ebrahim S, Davey Smith G, British women's heart and health study (2002) Socioeconomic position in childhood and adulthood and insulin resistance: cross sectional survey using data from British women's heart and health study. BMJ 325: 805-807.

5. Davey Smith G, Hart C (1997) Insulin resistance syndrome and childhood social conditions. Lancet 349: 284-285.

6. Davey Smith G, Greenwood R, Gunnell D, Sweetnam P, Yarnell J, et al (2001) Leg length, insulin resistance, and coronary heart disease risk: the Caerphilly Study. J Epidemiol Community Health 55: 867-872.

7. Lawlor DA, Davey SG, Ebrahim S (2002) Birth weight of offspring and insulin resistance in late adulthood: cross sectional survey. British Medical Journal 325: 359 .

8. Singhal A, Fewtrell M, Cole TJ, Lucas A (2003) Low nutrient intake and early growth for later insulin resistance in adolescents born preterm. Lancet 361: 1089-1097.
Although we documented slightly greater imprecision than would be expected in plasma or serum samples, our analysis of established associations of adiponectin levels with gender, adiposity measures, glucose and height, were in line with previously published results.[39-42] We did not observe an association of adiponectin with fasting insulin levels in our population of 11.5 year olds, in line with others indicating a complex relationship at this age. $[41,42]$ The mean values in girls and boys that we observed were slightly higher, but in line with other reports (given age, setting, population and sampling variation) (Table 4). [3942].

The advantages of filter paper capillary blood sampling, combined with the acceptable analytical performance characteristics of the dried blood spot assays, makes the approach ideal for large-scale epidemiologic applications, including studies of children, whenever the acceptability, stability, cost and safety of liquid sample collection and transportation to distant laboratories may be limiting factors (which may not be the case, however, for small and medium sized studies that are geographically contained). There are caveats, as we have previously pointed out, [37] including the need for adequate training for those taking the bloodspot samples onto filter paper, to avoid several sources of error, and the fact that we have developed the dried bloodspot assay for research and not clinical use, which would require additional investigation. [43].

\section{Supporting Information}

Figure S1 Bland-Altman plot for the ratio of bloodspot to plasma adiponectin values in 50 paired samples. Mean ratio of bloodspot to plasma adiponectin values: 1.57 (95\% CI: 1.47 to 1.67$)$. Range of ratio values: 0.97 to 2.39 .

(PPTX)

\section{Acknowledgments}

We thank Natalia Klochko for performing some of the assays.

\section{Author Contributions}

Conceived and designed the experiments: RMM EO MSK YF NG. Performed the experiments: AZ YF NG. Analyzed the data: RP JT AZ YF NG. Contributed reagents/materials/analysis tools: NS YF NG. Wrote the paper: RMM EO MSK YF. Acquisition of fieldwork data: NB KV NS. Supervision of fieldwork: NB KV NS. Administrative, technical and material support: RP JT AZ KV NB NS.

9. Ravelli ACJ, van der Meulen JH, Osmond C, Barker DJP, Bleker OP (2000) Infant feeding and adult glucose tolerance, lipid profile, blood pressure, and obesity. Arch Dis Child 82: 248-252.

10. Rung J, Cauchi S, Albrechtsen A, Shen L, Rocheleau G, et al (2009) Genetic variant near IRS1 is associated with type 2 diabetes, insulin resistance and hyperinsulinemia. Nature Genetics 41: 1110-1115.

11. Expert Panel on Detection Evaluation and Treatment of High Blood Cholesterol in Adults (2001) Executive Summary of the Third Report of the National Cholesterol Education Program (NCEP) Expert Panel on Detection, Evaluation, and Treatment of High Blood Cholesterol in Adults (Adult Treatment Panel III). JAMA 285: 2486-2497.

12. Nakano Y, Tobe T, Choi-Miura NH, Mazda T, Tomita M (1996) Isolation and characterization of GBP28, a novel gelatin-binding protein purified from human plasma. J Biochem (Tokyo) 120: 803-812.

13. Chandran M, Phillips SA, Ciaraldi T, Henry RR (2003) Adiponectin: more than just another fat cell hormone? Diabetes Care 26: 2442-2450.

14. Haffner SM, Lehto S, Ronnemaa T, Pyorala K, Laakso M (1998) Mortality from coronary heart disease in subjects with type 2 diabetes and in nondiabetic subjects with and without prior myocardial infarction. N Engl J Med 339: 229 234. 
15. Cho E, Rimm EB, Stampfer MJ, Willett WC, Hu FB (2002) The impact of diabetes mellitus and prior myocardial infarction on mortality from all causes and from coronary heart disease in men. J Am Coll Cardiol 40: 954-960.

16. Tsou PL, Jiang YD, Chang CC, Wei JN, Sung FC, et al (2004) Sex-Related Differences Between Adiponectin and Insulin Resistance in Schoolchildren. Diabetes Care 27: 308-313.

17. Asayama K, Hayashibe H, Dobashi K, Uchida N, Nakane T, et al (2003) Decrease in Serum Adiponectin Level Due to Obesity and Visceral Fat Accumulation in Children. Obesity Research 11: 1072-1079.

18. Shand BI, Scott RS, Elder PA, George PM (2003) Plasma adiponectin in overweight, nondiabetic individuals with or without insulin resistance. Diabetes, Obesity \& Metabolism 5: 349-353.

19. Stefan N, Bunt JC, Salbe AD, Funahashi T, Matsuzawa Y, et al (2002) Plasma adiponectin concentrations in children: relationships with obesity and insulinemia. Journal of Clinical Endocrinology \& Metabolism 87: 4652-4656.

20. Bacha F, Saad R, Gungor N, Arslanian SA (2004) Adiponectin in Youth: Relationship to visceral adiposity, insulin sensitivity, and beta-cell function. Diabetes Care 27: 547-552.

21. Hotta K, Funahashi T, Arita Y, Takahashi M, Matsuda M, et al (2000) Plasma Concentrations of a Novel, Adipose-Specific Protein, Adiponectin, in Type 2 Diabetic Patients. Arteriosclerosis, Thrombosis, and Vascular Biology 20: 15951599.

22. Weyer G, Funahashi T, Tanaka S, Hotta K, Matsuzawa Y, et al (2001) Hypoadiponectinemia in Obesity and Type 2 Diabetes: Close Association with Insulin Resistance and Hyperinsulinemia. J Clin Endocrinol Metab 86: 19301935.

23. Weiss R, Dufour S, Groszmann A, Petersen K, Dziura J, et al (2003) Low Adiponectin Levels in Adolescent Obesity: A Marker of Increased Intramyocellular Lipid Accumulation. Journal of Clinical Endocrinology \& Metabolism 88: 2014-2018.

24. Pischon T, Girman CJ, Hotamisligil GS, Rifai N, Hu FB, et al (2004) Plasma adiponectin levels and risk of myocardial infarction in men. JAMA 291: 1730 1737.

25. Tsao TS, Lodish HF, Fruebis J (2002) ACRP30, a new hormone controlling fat and glucose metabolism. Eur J Pharmacol 440: 213-221.

26. Matsubara M, Maruoka S, Katayose S (2002) Inverse relationship between plasma adiponectin and leptin concentrations in normal-weight and obese women. Eur J Endocrinol 147: 173-180.

27. Pischon T, Hotamisligil GS, Rimm EB (2003) Adiponectin: stability in plasma over 36 hours and within-person variation over 1 year. Clinical Chemistry 49: $650-652$.

28. Cruz M, Garcia-Macedo R, Garcia-Valerio Y, Gutierrez M, Medina-Navarro $\mathrm{R}$, et al (2004) Low Adiponectin Levels Predict Type 2 Diabetes in Mexican Children. Diabetes Care 27: 1451-1453.

29. Parker SP, Cubitt WD (1999) The use of the dried blood spot sample in epidemiological studies. J Clin Pathol 52: 633-639.

30. Lynch JF, Marshall MD, Wang XL, Wilcken DE (1998) Apolipoprotein screening in Australian children: feasibility and the effect of age, sex, and ethnicity. Medical Journal of Australia 168: 61-64.
31. Worthman CM, Stallings JF (1997) Hormone measures in finger-prick blood spot samples: new field methods for reproductive endocrinology. American Journal of Physical Anthropology 104: 1-21.

32. McDade TW, Williams S, Snodgrass JJ (2007) What a drop can do: dried blood spots as a minimally invasive method for integrating biomarkers into populationbased research. Demography 44: 899-925.

33. Klamer A, Skogstrand K, Hougaard DM, Norgaard-Petersen B, Juul A, et al (2007) Adiponectin levels measured in dried blood spot samples from neonates born small and appropriate for gestational age. Eur J Endocrinol 157: 189-194.

34. Kramer MS, Chalmers B, Hodnett ED, Sevkovskaya Z, Dzikovich I, et al (2001) Promotion of Breastfeeding Intervention Trial (PROBIT): a randomized trial in the Republic of Belarus. JAMA 285: 413-420.

35. MeiJV, Alexander JR, Adam BW, Hannon WH (2001) Use of Filter Paper for the Collection and Analysis of Human Whole Blood Specimens. J Nutr 131: 1631S-1636.

36. National Committee for Clinical Laboratory Standards (NCGLS) (1997) Blood Collection on Filter Paper for Neonatal Screening Programs, approved standard, National Committee for Clinical Laboratory Standards Document A4A3 3rd edition. Wayne, PA: National Committee for Clinical Laboratory Standards.

37. Martin RM, Patel R, Zinovik A, Kramer MS, Oken E, et al (2012) Filter Paper Blood Spot Enzyme Linked Immunoassay for Insulin and Application in the Evaluation of Determinants of Child Insulin Resistance. PLoS ONE 7: e46752.

38. Warnick GR, Leary ET, Ammirati EB, Allen MP (1994) Cholesterol in fingerstick capillary specimens can be equivalent to conventional venous measurements. Archives of Pathology \& Laboratory Medicine 118: 1110-1114.

39. Okada T, Saito E, Kuromori Y, Miyashita M, Iwata F, et al (2006) Relationship between serum adiponectin level and lipid composition in each lipoprotein fraction in adolescent children. Atherosclerosis 188: 179-183.

40. Singhal A, Jamieson N, Fewtrell M, Deanfield J, Lucas A, et al (2005) Adiponectin Predicts Insulin Resistance But Not Endothelial Function in Young, Healthy Adolescents. J Clin Endocrinol Metab 90: 4615-4621.

41. Punthakee Z, Delvin EE, O'Loughlin J, Paradis G, Levy E, et al (2006) Adiponectin, Adiposity, and Insulin Resistance in Children and Adolescents. Journal of Clinical Endocrinology \& Metabolism 91: 2119-2125.

42. Ong KK, Frystyk J, Flyvbjerg A, Petry CJ, Ness A, et al (2006) Sex-Discordant Associations With Adiponectin Levels and Lipid Profiles in Children. Diabetes 55: 1337-1341.

43. Williams SR, McDade TW (2009) The Use of Dried Blood Spot Sampling in the National Social Life, Health, and Aging Project. J GERONTOL B PSYCHOL SCI SOC SCI gbn022.

44. Cole TJ, Bellizzi MC, Flegal KM, Dietz WH (2000) Establishing a standard definition for child overweight and obesity worldwide: international survey. BMJ 320: $1240-1243$

45. Fernandez JR, Redden DT, Pietrobelli A, Allison DB (2004) Waist circumference percentiles in nationally representative samples of African-American, European-American, and Mexican-American children and adolescents. The Journal of Pediatrics 145: 439-444.

46. McDowell MA, Fryar CD, Ogden CL, Flegal KM (20108) Anthropometric Reference Data for Children and Adults: United States, 2003-2006. Hyattsville MD: National Center for Health Statistics. 